\title{
Pengaruh Model Pembelajaran Kooperatif Tipe Think-Talk-Write terhadap Kemampuan Komunikasi Matematis Siswa: Studi Meta-Analisis
}

\author{
Nurmala Setianing Putri ${ }^{1}$, Dadang Juandi ${ }^{2}$, Al Jupri ${ }^{3}$ \\ 1, 2, 3 Program Studi Pendidikan Matematika, Fakultas Pendidikan Matematika dan Ilmu Pengetahuan Alam, Universitas \\ Pendidikan Indonesia, \\ J1. Dr. Setia Budhi No. 229, Bandung, Indonesia \\ nurmalasetianingputri@upi.edu
}

\begin{abstract}
One of the mathematical abilities that need to be developed by students is mathematical communication ability. One of the appropriate learning models to improve mathematical communication ability is the Think-TalkWrite Type of Cooperative Learning Model. Through Google Scholar, Garuda Portal, ERIC, SAGE Publishing, and Springer Publishing, the authors obtained 114 journal and proceeding articles that discuss the effect of applying the Think-Talk-Write Type of Cooperative Learning Model towards students' mathematical communication ability, so it is necessary to analyze that collection of studies to find out how much effect the application of the Think-Talk-Write Type of Cooperative Learning Model towards students' mathematical communication ability using a meta-analysis research design. Of all the articles that the authors obtained, there were 19 articles that fulfills the inclusion criteria to be analyzed using the Comprehensive Meta-Analysis application in order to obtain a combined effect size. Based on the interpretation of that combined effect size, it can be concluded overall the application of the Think-Talk-Write Type of Cooperative Learning Model has a strong effect on students' mathematical communication ability. There are also study characteristics that are analyzed in this study, that include the year of research, education level and sample size. Statistically, it was found that the application of the Think-Talk-Write Type of Cooperative Learning Model to improve students' mathematical communication ability was only effected by the year of research.
\end{abstract}

Keywords: Think-Talk-Write Type of Cooperative Learning Model, Mathematical Communication Ability, Meta-Analysis

\begin{abstract}
Abstrak
Salah satu kemampuan matematis yang perlu dikembangkan oleh siswa adalah kemampuan komunikasi matematis. Salah satu model pembelajaran yang tepat untuk meningkatkan kemampuan komunikasi matematis adalah Model Pembelajaran Kooperatif Tipe Think-Talk-Write. Melalui Google Scholar, Portal Garuda, ERIC, SAGE Publishing dan Springer Publishing, penulis memperoleh 114 artikel jurnal maupun prosiding yang membahas pengaruh penerapan Model Pembelajaran Kooperatif Tipe Think-Talk-Write terhadap kemampuan komunikasi matematis siswa, sehingga perlu dilakukan analisis terhadap kumpulan studi tersebut untuk mengetahui seberapa besar pengaruh penerapan Model Pembelajaran Kooperatif Tipe Think-Talk-Write terhadap kemampuan komunikasi matematis siswa dengan menggunakan desain penelitian meta-analisis. Dari keseluruhan artikel yang penulis peroleh, terdapat 19 artikel yang memenuhi kriteria inklusi untuk dianalisis menggunakan aplikasi Comprehensive Meta-Analysis sehingga diperoleh besar ukuran efek gabungan. Berdasarkan interpretasi dari ukuran efek gabungan tersebut, dapat disimpulkan bahwa secara keseluruhan penerapan Model Pembelajaran Kooperatif Tipe Think-Talk-Write memberikan pengaruh yang kuat terhadap kemampuan komunikasi matematis siswa. Adapula karakteristik studi yang dianalisis dalam penelitian ini meliputi tahun penelitian, jenjang pendidikan dan ukuran sampel. Secara statistik, diperoleh bahwa penerapan Model Pembelajaran Kooperatif Tipe Think-Talk-Write untuk meningkatkan kemampuan komunikasi matematis siswa hanya dipengaruhi oleh tahun penelitian.
\end{abstract}

Kata kunci: Model Pembelajaran Kooperatif Tipe Think-Talk-Write, Kemampuan Komunikasi Matematis, Meta-Analisis

Copyright (c) 2022 Nurmala Setianing Putri, Dadang Juandi, Al Jupri

$\triangle$ Corresponding author: Nurmala Setianing Putri

Email Address: nurmalasetianingputri@ upi.edu (Jl. Dr. Setia Budhi No. 229, Bandung, Indonesia)

Received 04 January 2022, Accepted 05 February 2022, Published 08 February 2022

\section{PENDAHULUAN}

Seiring berkembangnya zaman, proses pembelajaran terus mengalami perubahan. Dalam pembelajaran abad ke-21, salah satu aspek yang turut mengalami perubahan adalah aspek penilaian 
pencapaian belajar siswa. Penilaian dalam pembelajaran abad ke-21 tersebut lebih menitikberatkan pada pengukuran kompetensi pengetahuan, kompetensi intrapersonal dan kompetensi interpersonal siswa (Muhali, 2019). Beberapa kompetensi yang diukur tersebut adalah kolaborasi dan komunikasi, yang termasuk ke dalam kompetensi pengetahuan dan intrapersonal siswa; kemampuan kerja dalam tim dan koordinasi, yang termasuk ke dalam kompetensi intrapersonal siswa; kerjasama yang termasuk ke dalam kompetensi intrapersonal dan interpersonal siswa; serta kemampuan secara emosional dalam menjaga hubungan dengan orang lain dan komunikasi yang efektif, yang termasuk ke dalam kompetensi interpersonal siswa (Muhali, 2019). Selain itu, aspek komunikasi juga merupakan aktivitas utama yang perlu didorong oleh guru dalam pembelajaran sebagai bagian dari proses mengkonstruksi pengetahuannya (Umar, 2012). Dengan demikian, terlihat bahwa kemampuan komunikasi dan kerja sama dalam kelompok menjadi hal yang diutamakan dan perlu dikembangkan dalam proses pembelajaran, baik itu melalui proses mengemukakan gagasan, diskusi, melakukan komunikasi secara tertulis, dan lain-lain.

Berkaitan dengan kemampuan komunikasi, dalam matematika terdapat kemampuan komunikasi matematis yang perlu dikembangkan oleh siswa. Kemampuan komunikasi matematis didefinisikan sebagai kemampuan untuk mengungkapkan, mendeskripsikan, dan mendiskusikan gagasan maupun konsep matematika secara runtut dan jelas (Lomibao dkk., 2016). Pengembangan kemampuan komunikasi matematis dalam pembelajaran matematika adalah hal yang sangat penting karena memiliki kemampuan komunikasi matematis yang baik akan membuat siswa mampu mengorganisasikan proses berpikir matematisnya baik secara lisan maupun tulisan (Umar, 2012). Dalam sebuah penelitian yang menggunakan teknik korelasi regresi juga disebutkan bahwa kemampuan komunikasi matematis siswa SMP memberikan pengaruh yang positif dan signifikan terhadap prestasi belajar matematika siswa (Astuti \& Leonard, 2015). Dengan demikian, kemampuan komunikasi matematis tidak hanya bermanfaat bagi siswa untuk membantu mereka dalam mengungkapkan dan menguraikan gagasan matematis yang dapat digunakan dalam memecahkan permasalahan matematis, tetapi juga dapat membantu siswa dalam meningkatkan hasil belajarnya.

Untuk mengembangkan kemampuan komunikasi matematis, perlu diciptakan pembelajaran matematika yang tepat dengan melibatkan kegiatan-kegiatan yang dapat melatih kemampuan komunikasi matematis siswa. Salah satu kegiatan yang melibatkan proses komunikasi secara umum, yang dapat dilakukan siswa dalam pembelajaran matematika adalah kegiatan berkomunikasi dengan siswa lainnya dalam suatu kelompok. Salah satu model pembelajaran yang telah banyak diterapkan dalam penelitian-penelitian dan dapat membantu siswa untuk meningkatkan kemampuan komunikasi matematis siswa adalah Model Pembelajaran Kooperatif Tipe Think-Talk-Write.

Model Pembelajaran Kooperatif Tipe Think-Talk-Write adalah model pembelajaran yang pada dasarnya menekankan pada dibangunnya proses berpikir, berbicara dan menulis dalam setiap proses pembelajaran, di mana proses berpikir terjadi dalam kegiatan mengkonstruksi dan memahami suatu materi melalui bahan pembelajaran yang diberikan oleh guru, proses berbicara terjadi dalam kegiatan 
berdiskusi untuk memperoleh pemahaman yang sama, dan proses menulis terjadi dalam kegiatan membuat rangkuman dari konsep-konsep yang siswa peroleh dan siswa pahami pada proses berbicara (Sa'diyah dkk., 2019). Model Pembelajaran Kooperatif Tipe Think-Talk-Write terdiri dari tiga tahap yakni tahap think, di mana siswa diberikan pernyataan dan lebih disarankan untuk diberikan permasalahan kontekstual atau permasalahan yang ada dalam kehidupan sehari-hari serta siswa memikirkan ide yang mereka peroleh dari permasalahan yang diberikan, bagaimana cara menyelesaikannya dan apa saja hal yang tidak boleh dilakukan dalam penyelesaian permasalahan tersebut; tahap talk, di mana siswa merefleksikan, menyusun, dan mengecek ide penyelesaian permasalahan melalui kegiatan diskusi kelompok; serta tahap write, di mana siswa menerapkan hasil yang diperoleh dari dua tahap sebelumnya yakni dengan menuliskan konsep yang berkaitan dengan permasalahan yang ada, strategi penyelesaian, dan solusi dari permasalahan tersebut (Jusniani dkk., 2020). Dengan demikian, Model Pembelajaran Kooperatif Tipe Think-Talk-Write ini diterapkan agar siswa dapat mengkonstruksi sendiri suatu konsep yang sedang dipelajarinya dan memahami konsep tersebut, melalui pernyataan atau permasalahan yang diberikan oleh guru.

Dari pemaparan tersebut, dapat dikatakan pula bahwa proses penerapan Model Pembelajaran Kooperatif Tipe Think-Talk-Write sangat berkaitan erat dengan kemampuan komunikasi matematis. Hal ini sejalan dengan pernyataan yang diungkapkan dalam sebuah studi yakni kemampuan komunikasi matematis merupakan bentuk aktivitas sosial yang tergolong ke dalam kegiatan "talking", dan aktivitas berfikir yang tergolong ke dalam kegiatan "writing" dan "thinking" (Umar, 2012). Dengan demikian, kemampuan komunikasi matematis ini dapat dilatih dan dikembangkan melalui pelaksanaan setiap tahap dalam Model Pembelajaran Kooperatif Tipe Think-Talk-Write yakni tahap thinking, talking, dan writing. Pada tahap thinking, siswa dilatih untuk dapat memahami permasalahan yang diberikan oleh guru, serta mulai memikirkan gagasan matematis yang dapat mengarah pada penyelesaian permasalahan atau mulai memikirkan cara mengkonstruksi suatu konsep melalui pernyataan atau permasalahan yang diberikan oleh guru tersebut. Kemudian pada tahap talking, siswa dilatih untuk bisa menggunakan kemampuan komunikasi matematisnya yang termasuk ke dalam jenis komunikasi verbal secara lisan maupun tulisan untuk mengungkapkan gagasan matematis terkait strategi penyelesaian baik disampaikan secara lisan maupun tulisan, serta mendiskusikan gagasan matematis dan strategi penyelesaian permasalahan tersebut dengan siswa lainnya. Selanjutnya, pada tahap writing, siswa juga dilatih untuk bisa menggunakan kemampuan komunikasi matematisnya yang termasuk ke dalam jenis komunikasi verbal secara tulisan untuk menggunakan gagasan matematis dan strategi penyelesaian tersebut, sehingga dapat membantu siswa dalam menyelesaikan permasalahan matematis yang diberikan oleh guru.

Hal penting lainnya dalam proses pembelajaran selain untuk meningkatkan kemampuan komunikasi matematis adalah bagaimana cara guru menerapkan pembelajaran tersebut. Proses bekerjasama antara kelompok maupun dalam kelompok merupakan hal penting yang perlu diterapkan oleh guru dalam pembelajaran seiring berkembangnya ilmu pengetahuan dan teknologi (Capar \& 
Tarim, 2015). Kegiatan bekerja sama dalam kelompok dapat terlihat dalam penerapan model pembelajaran kooperatif yang diharapkan dapat mendorong siswa untuk ikut berpartisipasi aktif dalam pembelajaran dan dapat membantu siswa agar mencapai tujuan pembelajaran. Penerapan model pembelajaran kooperatif ini juga bertujuan agar siswa dapat lebih mudah memahami materi pelajaran melalui proses kerja kelompok, siswa mengalami peningkatan dalam kemampuan sosialnya, siswa mampu menerima dan menghargai perbedaan, serta terlatih untuk membantu sesama teman agar dapat sama-sama memahami materi dengan baik.

Dikarenakan telah banyak studi yang membahas tentang pengaruh penerapan Model Pembelajaran Kooperatif Tipe Think-Talk-Write terhadap kemampuan komunikasi matematis siswa, maka penulis perlu menganalisis, menggabungkan dan mensintesis kumpulan studi tersebut untuk mengetahui seberapa besar pengaruh penerapan Model Pembelajaran Kooperatif Tipe Think-TalkWrite terhadap kemampuan komunikasi matematis siswa dibandingkan dengan Model Pembelajaran Konvensional. Selain itu, penulis juga perlu menganalisis beberapa karakteristik studi seperti tahun penelitian, jenjang pendidikan, dan ukuran sampel, sehingga hasil penelitian ini dapat dijadikan acuan bagi penentu kebijakan mengenai bagaimana penerapan Model Pembelajaran Kooperatif Tipe ThinkTalk-Write yang efektif dengan mempertimbangkan beberapa karakteristik studi tersebut agar penerapan Model Pembelajaran Kooperatif Tipe Think-Talk-Write dapat membantu meningkatkan dan memperbaiki kualitas pembelajaran di sekolah khususnya pada kemampuan komunikasi matematis siswa.

\section{METODE}

Desain penelitian yang digunakan dalam penelitian ini adalah meta-analisis, yaitu metode statistika yang digunakan untuk menggabungkan, menganalisis dan mensintesis dua atau lebih studi yang ada secara sistematis untuk memperoleh temuan baru dan kesimpulan umum dari studi-studi tersebut menggunakan ukuran efek studi (Nelson, 2015; Shah dkk., 2020; Shelby \& Vaske, 2008). Penelitian ini bertujuan untuk menggabungkan, menganalisis, dan mensintesis secara statistik dan sistematis, temuan dari dua atau lebih studi yang meneliti tentang pengaruh penerapan Model Pembelajaran Kooperatif Tipe Think-Talk-Write terhadap kemampuan komunikasi matematis siswa. Langkah-langkah yang harus dilakukan dalam penelitian meta-analisis antara lain menentukan kriteria inklusi studi; melakukan pencarian literatur dan penyeleksian studi; melakukan pengkodean studi; melakukan analisis statistik dengan menghitung ukuran efek, melakukan uji homogenitas untuk menentukan model analisis yang akan digunakan, mendeteksi bias dan mengatasi bias, menguji hipotesis nol, menganalisis karakteristik studi serta membuat interpretasi dari hasil analisis tersebut (Retnawati dkk., 2018). Langkah-langkah tersebut adalah langkah-langkah yang digunakan dalam penelitian meta-analisis ini.

Adapun kriteria inklusi untuk studi primer yang digunakan dalam penelitian meta-analisis ini antara lain populasi dalam studi primer meliputi siswa pada jenjang sekolah dasar, sekolah menengah 
pertama, dan sekolah menengah atas di Indonesia; perlakuan yang diberikan kepada kelompok eksperimen dalam studi primer adalah Model Pembelajaran Kooperatif Tipe Think-Talk-Write sedangkan perlakuan yang diberikan kepada kelompok kontrol dalam studi primer adalah Model Pembelajaran Konvensional; hasil dalam studi primer adalah kemampuan komunikasi matematis; jenis penelitian dalam studi primer adalah quasi eksperimen dengan desain penelitian randomized control group pretest-posttest design, randomized control group posttest only design, nonequivalent qroup pretest-posttest design, dan nonequivalent qroup design posttest only; data statistik yang tersedia dalam studi primer meliputi ukuran sampel, rata-rata, dan standar deviasi; dan tahun publikasi studi primer adalah antara tahun 2012 sampai dengan 2021.

Dalam melakukan pencarian literatur berupa artikel jurnal dan prosiding yang memiliki topik penelitian tentang pengaruh penerapan Model Pembelajaran Kooperatif Tipe Think-Talk-Write terhadap kemampuan komunikasi matematis siswa, penulis menggunakan beberapa database seperti Google Scholar, Portal Garuda, ERIC, SAGE Publishing dan Springer Publishing. Kata kunci yang digunakan penulis untuk memudahkan dalam pencarian literatur meliputi "Think-Talk-Write, Mathematical Communication Ability”, “Think-Talk-Write, Kemampuan Komunikasi Matematis”, "TTW, Mathematical Communication Ability", dan "TTW, Kemampuan Komunikasi Matematis". Dari pencarian literatur tersebut diperoleh artikel jurnal dan prosiding dengan tahun publikasi 20122021 sebanyak 114 buah. Selanjutnya, 114 artikel tersebut diseleksi oleh penulis dengan menyesuaikan pada kriteria inklusi yang telah penulis tentukan sebelumnya. Studi yang memenuhi kriteria inklusi ada sebanyak 19 buah dengan jenjang pendidikan SMP/MTs dan SMA/MA/SMK. Dengan demikian, terdapat 19 buah studi yang digunakan dalam penelitian meta-analisis ini.

Adapun langkah selanjutnya adalah melakukan pengkodean studi. Instrumen penelitian yang digunakan dalam langkah ini adalah protokol pengkodean yang meliputi form pengkodean yang berbentuk kertas atau komputerisasi, dan manual pengkodean yakni panduan yang berisi instruksi tentang tata cara mengkodekan setiap item sesuai data yang tersedia dalam studi primer (Wilson, 2009). Pengkodean studi meliputi beberapa informasi yang akan digunakan dalam proses metaanalisis yaitu kode studi; penulis; tahun publikasi; rata-rata, standar deviasi dan jumlah sampel kelompok eksperimen; rata-rata, standar deviasi dan jumlah sampel kelompok kontrol; tahun penelitian; jenjang pendidikan; dan ukuran sampel. Tahun penelitian dibagi ke dalam lima kategori yaitu 2012-2013, 2014-2015, 2016-2017, 2018-2019, dan 2020-2021; jenjang pendidikan dibagi ke dalam dua kategori yaitu SMP/MTs dan SMA/MA/SMK; sedangkan ukuran sampel dibagi ke dalam dua kategori yaitu 30 atau kurang, dan 31 atau lebih.

Setelah proses pengkodean dilakukan, maka penulis menghitung ukuran efek. Dikarenakan penulis akan mengukur perbedaan antara dua kelompok independen yaitu kelompok yang memperoleh pembelajaran dengan Model Pembelajaran Kooperatif Tipe Think-Talk-Write dan kelompok yang memperoleh pembelajaran dengan Model Pembelajaran Konvensional serta studi primer yang digunakan dalam penelitian meta-analisis ini memiliki ukuran sampel yang kecil dan 
standar deviasi untuk sampel, maka ukuran efek yang digunakan dalam penelitian ini adalah ukuran efek berdasarkan standardized mean difference yaitu Hedges's g (Fritz dkk., 2012). Adapun interpretasi ukuran efek yang akan digunakan dalam penelitian meta-analisis ini adalah klasifikasi menurut Cohen, yakni sebagai berikut (Cohen dkk., 2007):

Tabel 1. Interpretasi Ukuran Efek

\begin{tabular}{|c|c|}
\hline ES & Interpretasi \\
\hline $0 \leq \mathrm{ES} \leq 0,20$ & Efek lemah \\
\hline $0,20<\mathrm{ES} \leq 0,50$ & Efek sederhana \\
\hline $0,50<\mathrm{ES} \leq 1,00$ & Efek sedang \\
\hline $\mathrm{ES}>1,00$ & Efek kuat \\
\hline
\end{tabular}

Setelah ukuran efek dihitung, maka perlu dilakukan uji homogenitas untuk menentukan model analisis yang akan digunakan dengan menggunakan p-value pada Q-statistic (Hedges, 2009; Retnawati dkk., 2018). Jika nilai p-value < 0,05, maka distribusi ukuran efek studi primer yang digunakan dalam meta-analisis bersifat heterogen, sehingga model analisis yang digunakan adalah model efek acak sedangkan jika nilai p-value > 0,05, maka distribusi ukuran efek studi primer yang digunakan dalam meta-analisis bersifat homogen, sehingga model analisis yang digunakan adalah model efek tetap (Retnawati dkk., 2018). Selanjutnya, agar studi yang digunakan dalam meta-analisis ini mewakili semua studi yang membahas pertanyaan penelitian yang sama serta tidak muncul klaim bahwa studi yang dipublikasikan dan yang digunakan dalam meta-analisis ini bukan hanya studi yang hasilnya signifikan, maka penulis perlu mendeteksi dan mengatasi bias publikasi (Greenhouse \& Iyengar, 2009). Beberapa metode yang dapat dilakukan untuk mendeteksi dan mengatasi bias publikasi antara lain funnel plot dan Fail-Safe N (FSN) Rosenthal (Retnawati dkk., 2018). Langkah pertama dalam mendeteksi bias publikasi adalah dengan menggunakan funnel plot. Jika distribusi ukuran efek studi tampak berbentuk asimetris atau tidak sepenuhnya berbentuk simetris, maka perlu digunakan Fail-Safe N (FSN) Rosenthal untuk membantu menentukan apakah terdapat kemungkinan bias publikasi atau tidak (Tamur dkk., 2020). Jika tidak terdapat bias publikasi, maka penulis dapat langsung melanjutkan proses analisis. Dengan menggunakan model analisis yang telah ditentukan sebelumnya, penulis dapat melakukan uji hipotesis nol (Retnawati dkk., 2018). Jika nilai p-value < 0,05, maka hipotesis nol diterima yaitu penerapan Model Pembelajaran Kooperatif Tipe Think-TalkWrite memberikan pengaruh yang signifikan terhadap kemampuan komunikasi matematis siswa dibandingkan Model Pembelajaran Konvensional. Apabila model analisis yang digunakan adalah model efek random yang artinya terdapat perbedaan pada karakteristik studi, maka penulis dapat melakukan analisis terhadap karakteristik studi tersebut dan kemudian menginterpretasikan hasil analisisnya (Borenstein dkk., 2010). 


\section{HASIL DAN DISKUSI}

Tujuan utama dari penelitian meta-analisis ini adalah untuk mengetahui ukuran efek gabungan penerapan Model Pembelajaran Kooperatif Tipe Think-Talk-Write terhadap kemampuan komunikasi matematis siswa sehingga diperoleh hasil tentang pengaruh penerapan Model Pembelajaran Kooperatif Tipe Think-Talk-Write tersebut terhadap kemampuan komunikasi matematis siswa. Daftar studi yang digunakan dalam meta-analisis disajikan dalam Tabel 2.

Tabel 2. Studi yang Digunakan dalam Meta-Analisis

\begin{tabular}{|c|c|c|}
\hline $\begin{array}{l}\text { Kode } \\
\text { Studi }\end{array}$ & Jud & $\begin{array}{c}\text { Nama } \\
\text { Jurnal/Prosiding } \\
\end{array}$ \\
\hline Studi 1 & $\begin{array}{l}\text { Secondary School Students' Mathematical Communication } \\
\text { Through Think-Talk-Write (TTW) Learning Model and } \\
\text { Interactive Media }\end{array}$ & $\begin{array}{l}\text { Journal of Physics: } \\
\text { Conference Series }\end{array}$ \\
\hline Studi 2 & $\begin{array}{l}\text { Mengembangkan Kemampuan Komunikasi Matematik Siswa } \\
\text { Melalui Strategi Think Talk Write }\end{array}$ & $\begin{array}{l}\text { Jurnal } \\
\text { "Mosharafa" }\end{array}$ \\
\hline Studi 3 & $\begin{array}{l}\text { The Effect of Think Talk Write Learning Model with Batak } \\
\text { Toba Culture Context toward Students Mathematical } \\
\text { Communication Skill of SMP Swasta Parulian } 2 \text { Medan }\end{array}$ & $\begin{array}{l}\text { American Journal } \\
\text { of Educational } \\
\text { Research }\end{array}$ \\
\hline Studi 4 & $\begin{array}{l}\text { Peningkatan Kemampuan Komunikasi Matematik Siswa yang } \\
\text { Menggunakan Model Pembelajaran Kooperatif Tipe Think- } \\
\text { Talk-Write pada Materi Bangun Datar Segi Empat Kelas VII } \\
\text { SMP Swasta Nusantara Lubuk Pakam }\end{array}$ & $\begin{array}{l}\text { Seminar Nasional } \\
\text { Matematika } \\
\text { (SEMNASTIKA) } \\
2017\end{array}$ \\
\hline Studi 5 & $\begin{array}{l}\text { Pengaruh Pembelajaran Think-Talk-Write terhadap } \\
\text { Kemampuan Komunikasi Matematik dan Sikap Positif Siswa } \\
\text { terhadap Matematika }\end{array}$ & $\begin{array}{l}\text { Journal of Didactic } \\
\text { Mathematics }\end{array}$ \\
\hline Studi 6 & $\begin{array}{l}\text { Efektivitas Pembelajaran Kooperatif Tipe Think Talk Write } \\
\text { Ditinjau dari Kemampuan Komunikasi Matematis }\end{array}$ & $\begin{array}{l}\text { Jurnal P } \\
\text { Matemati }\end{array}$ \\
\hline Studi 7 & $\begin{array}{l}\text { mpuan Komunikasi dan Self Efficacy } \\
\text { IP Melalui Strategi Think Talk Write }\end{array}$ & Jurnal Numeracy \\
\hline Studi 8 & $\begin{array}{l}\text { Pengaruh Penerapan Strategi Pembelajaran Think Talk Write } \\
\text { terhadap Kemampuan Komunikasi Matematis Siswa }\end{array}$ & $\begin{array}{l}\text { Jurnal Pendidikan } \\
\text { Matematika } \\
\text { Universitas } \\
\text { Lampung }\end{array}$ \\
\hline Studi 9 & $\begin{array}{l}\text { K Talk Write terhadap } \\
\text { Masalah }\end{array}$ & $\begin{array}{l}\text { Belajea: Jurnal } \\
\text { Pendidikan Islam }\end{array}$ \\
\hline Studi 10 & $\begin{array}{l}\text { Pengaruh Model Pembelajaran Kooperatif Tipe Think Talk } \\
\text { Write terhadap Kemampuan Komunikasi Matematis }\end{array}$ & $\begin{array}{l}\text { Jurnal Pendidikan } \\
\text { Matematika } \\
\text { Universitas } \\
\text { Lampung }\end{array}$ \\
\hline Studi 11 & $\begin{array}{l}\text { Pengaruh Model Pembelajaran Kooperatif Tipe Think-Talk- } \\
\text { Write (TTW) terhadap Kemampuan Komunikasi Matematis } \\
\text { Peserta Didik Kelas VIII SMP Negeri } 3 \text { Padang }\end{array}$ & $\begin{array}{l}\text { Jurnal Edukasi dan } \\
\text { Penelitian } \\
\text { Matematika }\end{array}$ \\
\hline Studi 12 & $\begin{array}{l}\text { Meningkatkan Kemampuan Komunikasi dan Koneksi } \\
\text { Matematik Siswa SMP Melalui Strategi Think Talk Write }\end{array}$ & Jurnal Buana Ilmu \\
\hline Studi 13 & $\begin{array}{l}\text { Penerapan Model Pembelajaran Think Talk Write terhadap } \\
\text { Kemampuan Komunikasi Matematis Siswa Kelas X IPA }\end{array}$ & $\begin{array}{l}\text { INDIKTIKA } \\
\text { (Jurnal Inovasi } \\
\text { Pendidikan } \\
\text { Matematika) }\end{array}$ \\
\hline Studi 14 & $\begin{array}{l}\text { Pengaruh Penerapan Model Pembelajaran Kooperatif Tipe } \\
\text { Think Talk Write terhadap Kemampuan Komunikasi } \\
\text { Matematis Siswa Kelas XI IPA MAN Kota Padang }\end{array}$ & $\begin{array}{ll}\text { Math } & \text { Educa } \\
\text { Journal }\end{array}$ \\
\hline
\end{tabular}




\begin{tabular}{|c|l|l|}
\hline $\begin{array}{c}\text { Kode } \\
\text { Studi }\end{array}$ & \multicolumn{1}{|c|}{ Judul Studi } & \multicolumn{1}{|c|}{\begin{tabular}{c}
\multicolumn{1}{|c|}{ Nama } \\
Jurnal/Prosiding
\end{tabular}} \\
\hline Studi 15 & $\begin{array}{l}\text { Pengaruh Model Pembelajaran Think Talk Write terhadap } \\
\text { Kemampuan Komunikasi Matematis Siswa Kelas X SMK } \\
\text { Swasta Napsi'ah Stabat Tahun Pelajaran 2019/2020 }\end{array}$ & $\begin{array}{l}\text { Jurnal Serunai } \\
\text { Matematika }\end{array}$ \\
\hline Studi 16 & $\begin{array}{l}\text { Perbandingan Kemampuan Komunikasi Matematis Siswa yang } \\
\text { Diajar dengan Model Pembelajaran Kooperatif Tipe Think } \\
\text { Talk Write (TTW) dan Pembelajaran Konvensional }\end{array}$ & $\begin{array}{l}\text { Jurnal Penelitian } \\
\text { Pendidikan } \\
\text { Matematika }\end{array}$ \\
\hline Studi 17 & $\begin{array}{l}\text { Pengaruh Model Pembelajaran Think Talk Write terhadap } \\
\text { Kemampuan Komunikasi Matematika di SMPN 13 Padang }\end{array}$ & $\begin{array}{l}\text { Jurnal Edukasi dan } \\
\text { Penelitian } \\
\text { Matematika }\end{array}$ \\
\hline Studi 18 & $\begin{array}{l}\text { Meningkatkan Kemampuan Matematik Siswa Melalui } \\
\text { Pembelajaran Berbasis Masalah dan Strategi Think Talk and } \\
\text { Write }\end{array}$ & $\begin{array}{l}\text { Jurnal Pendidikan dan } \\
\text { Pengajaran San }\end{array}$ \\
\hline Studi 19 & $\begin{array}{l}\text { Kemampuan Komunikasi dan Pemecahan Masalah Matematis } \\
\text { Siswa SMP dengan Pendekatan Kontekstual dan Strategi } \\
\text { Think-Talk-Write }\end{array}$ & $\begin{array}{l}\text { Jurnal Serambi } \\
\text { Ilmu }\end{array}$ \\
\hline
\end{tabular}

Dengan menggunakan aplikasi Comprehensive Meta-Analysis Version 3, diperoleh efek studi, standar error dan interval kepercayaan masing-masing studi berdasarkan standardized mean difference yaitu Hedges's $g$ yang disajikan pada Tabel 3 .

Tabel 3. Ukuran Efek, Interpretasi Ukuran Efek, Standar Error, dan Interval Kepercayaan Setiap Studi

\begin{tabular}{|c|c|c|c|c|c|c|c|}
\hline \multirow{2}{*}{$\begin{array}{l}\text { Kode } \\
\text { Studi }\end{array}$} & \multirow{2}{*}{ Penulis } & \multirow{2}{*}{$\begin{array}{l}\text { Tahun } \\
\text { Publikasi }\end{array}$} & \multirow{2}{*}{$\begin{array}{c}\text { Ukuran } \\
\text { Efek }\end{array}$} & \multirow{2}{*}{$\begin{array}{c}\text { Interpretasi } \\
\text { Ukuran } \\
\text { Efek }\end{array}$} & \multirow{2}{*}{ SE } & \multicolumn{2}{|c|}{$\begin{array}{c}\text { Interval } \\
\text { Kepercayaan }\end{array}$} \\
\hline & & & & & & $\begin{array}{c}\text { Batas } \\
\text { Bawah }\end{array}$ & $\begin{array}{c}\text { Batas } \\
\text { Atas } \\
\end{array}$ \\
\hline Studi 1 & Jusniani, dkk. & 2020 & 128,022 & Kuat & 10,598 & 107,251 & 148,793 \\
\hline Studi 2 & Nuraeni \& Luritawaty & 2016 & 2,775 & Kuat & 0,338 & 2,113 & 3,437 \\
\hline Studi 3 & Sitompul, dkk. & 2019 & 2,019 & Kuat & 0,273 & 1,484 & 2,554 \\
\hline Studi 4 & Fadilla & 2017 & 1,672 & Kuat & 0,275 & 1,132 & 2,212 \\
\hline Studi 5 & Habeahan, dkk. & 2021 & 0,868 & Sedang & 0,234 & 0,410 & 1,326 \\
\hline Studi 6 & Yanti, dkk. & 2017 & 0,697 & Sedang & 0,261 & 0,186 & 1,208 \\
\hline Studi 7 & Aulia & 2018 & 0,721 & Sedang & 0,236 & 0,258 & 1,184 \\
\hline Studi 8 & Setiowati, dkk. & 2014 & 1,342 & Kuat & 0,290 & 0,774 & 1,911 \\
\hline Studi 9 & Putri & 2017 & 1,310 & Kuat & 0,314 & 0,694 & 1,925 \\
\hline Studi 10 & Oktarini, dkk. & 2014 & 0,626 & Sedang & 0,244 & 0,147 & 1,105 \\
\hline Studi 11 & Putri \& Syarifuddin & 2018 & 0,951 & Sedang & 0,281 & 0,399 & 1,502 \\
\hline Studi 12 & Nurapriani & 2016 & 0,249 & Sederhana & 0,252 & $-0,245$ & 0,742 \\
\hline Studi 13 & Wulandari, dkk. & 2020 & 0,200 & Lemah & 0,248 & $-0,286$ & 0,685 \\
\hline Studi 14 & Irwan & 2017 & 0,810 & Sedang & 0,233 & 0,352 & 1,267 \\
\hline Studi 15 & $\begin{array}{ll}\text { Ramadhani } & \& \\
\text { Zulhayana } & \\
\end{array}$ & 2020 & 4,453 & Kuat & 0,465 & 3,542 & 5,363 \\
\hline Studi 16 & Abidin \& Salam & 2013 & 0,498 & Sederhana & 0,231 & 0,046 & 0,951 \\
\hline Studi 17 & Anggraini, dkk. & 2018 & 0,477 & Sederhana & 0,247 & $-0,006$ & 0,961 \\
\hline Studi 18 & Hendriana & 2014 & 0,518 & Sedang & 0,231 & 0,065 & 0,971 \\
\hline Studi 19 & Junaidi \& Taufiq & 2019 & 0,683 & Sedang & 0,274 & 0,146 & 1,220 \\
\hline
\end{tabular}


Berdasarkan Tabel 3, masing-masing studi memiliki ukuran efek yang bervariasi di mana 18 studi memiliki ukuran efek yang berada dalam rentang 0,200 sampai dengan 4,453, dan ada 1 studi yang memiliki ukuran efek yang sangat tinggi dibandingkan studi-studi lainnya yakni sebesar 128,022. Dengan melakukan interpretasi ukuran efek menurut klasifikasi Cohen, diperoleh informasi bahwa 7 studi memiliki ukuran efek kuat yang artinya penerapan Model Pembelajaran Kooperatif Tipe Think-Talk-Write pada 7 studi tersebut berpengaruh kuat terhadap kemampuan komunikasi matematis siswa, 8 studi memiliki ukuran efek sedang yang artinya penerapan Model Pembelajaran Kooperatif Tipe Think-Talk-Write pada 8 studi tersebut berpengaruh sedang terhadap kemampuan komunikasi matematis siswa, 3 studi memiliki ukuran efek sederhana yang artinya penerapan Model Pembelajaran Kooperatif Tipe Think-Talk-Write pada 3 studi tersebut berpengaruh sederhana terhadap kemampuan komunikasi matematis siswa dan 1 studi memiliki ukuran efek lemah yang artinya penerapan Model Pembelajaran Kooperatif Tipe Think-Talk-Write pada studi tersebut berpengaruh lemah terhadap kemampuan komunikasi matematis siswa.

Untuk mengetahui ukuran efek gabungan seluruh studi primer, maka penulis perlu menentukan model estimasi yang akan digunakan dengan menguji homogenitas seluruh studi primer terlebih dahulu. Informasi yang dibutuhkan untuk melakukan uji homogenitas seluruh studi primer disajikan pada Tabel 4.

Tabel 4. Heterogenitas Distribusi Ukuran Efek

\begin{tabular}{|c|c|c|c|}
\hline \multicolumn{4}{|c|}{ Heterogenitas } \\
\hline Q-value & df $(\mathbf{Q})$ & P-value & I-squared \\
\hline 288,118 & 18 & 0,000 & 93,753 \\
\hline
\end{tabular}

Berdasarkan Tabel 4, diperoleh p-value $<0,05$, maka distribusi ukuran efek studi primer yang digunakan dalam meta-analisis bersifat heterogen. Dengan demikian model estimasi yang akan digunakan untuk mengetahui ukuran efek gabungan adalah model efek acak.

Selanjutnya, penulis perlu mendeteksi bias publikasi, penulis menggunakan funnel plot yang disajikan pada Gambar 1.

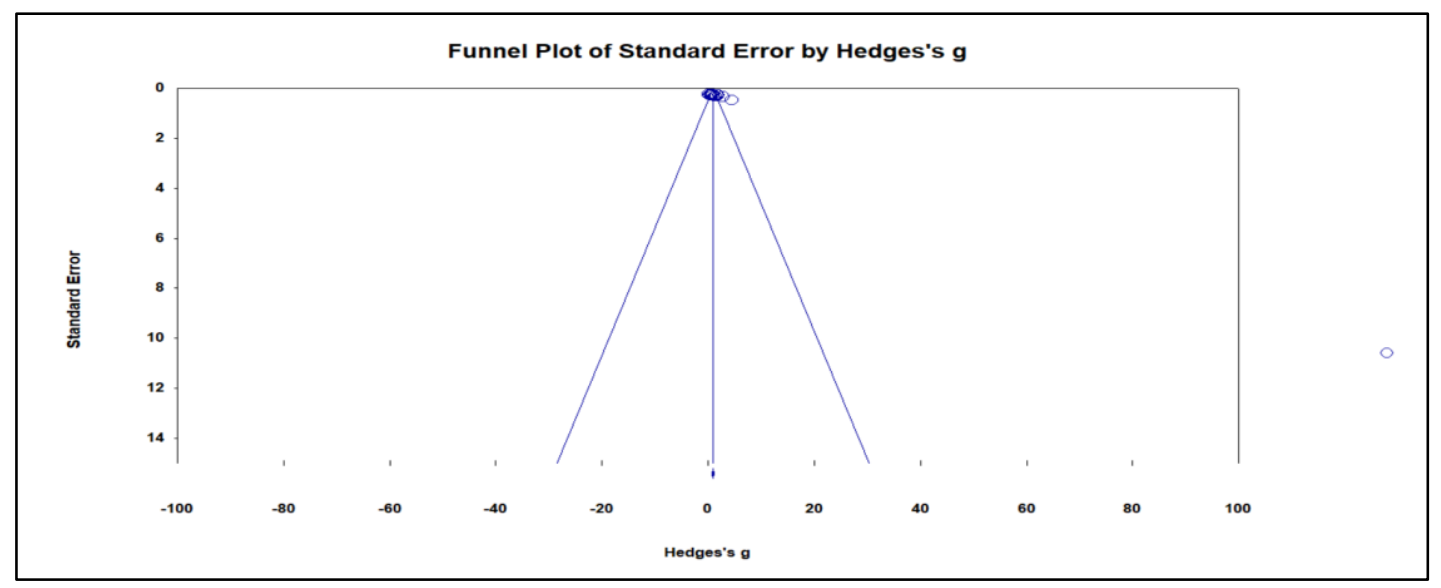

Gambar 1. Funnel Plot 
Berdasarkan Gambar 1, diperoleh bahwa distribusi ukuran efek studi berbentuk asimetris. Dengan demikian, penulis perlu mendeteksi bias publikasi menggunakan Fail-Safe $\mathrm{N}$ yang informasinya disajikan pada Tabel 5.

Tabel 5. Kondisi Bias Berdasarkan Fail-Safe N

\begin{tabular}{|l|r|}
\hline Kondisi Bias & \\
\hline Z-value untuk studi yang diamati & 18,72513 \\
\hline P-value untuk studi yang diamati & 0,00000 \\
\hline Alpha & 0,05 \\
\hline Tails & 2 \\
\hline Z untuk Alpha & 1,95996 \\
\hline Jumlah Studi Teramati & 19 \\
\hline FSN & 1716 \\
\hline
\end{tabular}

Dengan menggunakan rumus $\frac{F S N}{5 k+10}$, di mana nilai FSN dan k (jumlah studi teramati) disajikan pada Tabel 5, diperoleh $\frac{1716}{5(19)+10}=\frac{1716}{95+10}=\frac{1716}{105}=16,34>1$. Karena hasil perhitungan $\frac{F S N}{5 k+10}>1$, maka dapat disimpulkan bahwa studi yang digunakan dalam meta-analisis ini memenuhi toleransi yang cukup terhadap bias publikasi (Juandi \& Tamur, 2021).

Selanjutnya, pada Tabel 6 disajikan hasil meta-analisis studi primer dengan menggunakan model efek tetap dan model efek acak.

Tabel 6. Hasil Meta-Analisis Berdasarkan Model Estimasi

\begin{tabular}{|c|c|c|c|c|c|c|c|c|}
\hline \multirow{2}{*}{ Model } & \multirow{4}{*}{} & \multicolumn{4}{|c|}{ Ukuran Efek dan Interval Kepercayaan 95\% } & \multicolumn{2}{c|}{$\begin{array}{c}\text { Test of null (2- } \\
\text { Tail) }\end{array}$} \\
\cline { 3 - 9 } & $\mathbf{n}$ & $\begin{array}{c}\text { Ukuran } \\
\text { Efek }\end{array}$ & SE & Varians & $\begin{array}{c}\text { Batas } \\
\text { Bawa } \\
\text { h }\end{array}$ & $\begin{array}{c}\text { Batas } \\
\text { Atas }\end{array}$ & Z-value & P-value \\
\hline Model Efek Tetap & 19 & 0,939 & 0,062 & 0,004 & 0,817 & 1,060 & 15,135 & 0,000 \\
\hline Model Efek Acak & 19 & 1,206 & 0,256 & 0,066 & 0,704 & 1,707 & 4,708 & 0,000 \\
\hline
\end{tabular}

Melalui uji homogenitas studi primer sebelumnya, telah diketahui bahwa distribusi ukuran efek studi bersifat heterogen, maka model analisis yang digunakan adalah model efek acak. Berdasarkan Tabel 6 pada baris model efek acak, diperoleh nilai p-value pada uji Z sebesar 0,000. Karena p-value $<0,05$ maka dapat disimpulkan bahwa secara keseluruhan penerapan Model Pembelajaran Kooperatif Tipe Think-Talk-Write memberikan pengaruh yang lebih signifikan terhadap kemampuan komunikasi matematis siswa dibandingkan dengan penerapan Model Pembelajaran Konvensional. Hal ini sejalan dengan penelitian lainnya yang menganalisis pengaruh penerapan Model Pembelajaran Kooperatif secara umum terhadap prestasi matematika siswa, di mana penerapan Model Pembelajaran Kooperatif secara umum memberikan pengaruh yang lebih signifikan terhadap prestasi matematika siswa dibandingkan dengan penerapan Model Pembelajaran Konvensional, namun ukuran efeknya tergolong sedang (Capar \& Tarim, 2015). Selain itu, dalam penelitian ini diperoleh ukuran efek gabungan sebesar 1,206, sehingga berdasarkan klasifikasi Cohen, ukuran efek gabungan tersebut tergolong ukuran efek yang kuat. Dengan demikian, dapat disimpulkan pula bahwa secara 
keseluruhan penerapan Model Pembelajaran Kooperatif Tipe Think-Talk-Write memberikan pengaruh yang kuat terhadap kemampuan komunikasi matematis siswa. Selain itu, ukuran efek gabungan sebesar 1,206 menandakan bahwa rata-rata kemampuan komunikasi matematis siswa di kelompok eksperimen melebihi kemampuan komunikasi matematis 88\% siswa di kelompok kontrol (Coe, 2002).

Karena telah diketahui bahwa distribusi ukuran efek studi primer tersebut bersifat heterogen, maka penulis perlu menganalisis karakteristik studi yang menyebabkan terjadinya heterogenitas pada kemampuan komunikasi matematis siswa. Hasil meta-analisis untuk karakteristik studi tahun penelitian, jenjang pendidikan, dan ukuran sampel disajikan pada Tabel 7.

Tabel 7. Hasil Meta-Analisis Setiap Karakteristik Studi

\begin{tabular}{|c|c|c|c|c|c|c|c|c|}
\hline \multirow{2}{*}{$\begin{array}{c}\text { Karakteristik } \\
\text { Studi }\end{array}$} & \multirow[b]{2}{*}{ Kategori } & \multirow[b]{2}{*}{$\mathbf{n}$} & \multirow{2}{*}{$\begin{array}{l}\text { Hedges's } \\
\text { g }\end{array}$} & \multicolumn{2}{|c|}{$\begin{array}{l}\text { Test of null } \\
\text { (2-Tail) }\end{array}$} & \multicolumn{3}{|c|}{ Heterogeneity } \\
\hline & & & & $\begin{array}{c}\mathrm{Z}- \\
\text { value }\end{array}$ & $\begin{array}{l}\text { P- } \\
\text { value }\end{array}$ & $\begin{array}{c}\text { Q- } \\
\text { value }\end{array}$ & df $(Q)$ & $\begin{array}{c}\text { P- } \\
\text { value }\end{array}$ \\
\hline \multirow{7}{*}{ Tahun Penelitian } & $2012-2013$ & 3 & 0,607 & 4,537 & 0,000 & 1,124 & 2 & 0,570 \\
\hline & 2014-2015 & 3 & 1,357 & 8,301 & 0,000 & 26,585 & 2 & 0,000 \\
\hline & 2016-2017 & 6 & 0,797 & 7,484 & 0,000 & 19,431 & 5 & 0,002 \\
\hline & $2018-2019$ & 6 & 1,214 & 9,428 & 0,000 & 221,878 & 5 & 0,000 \\
\hline & $2020-2021$ & 1 & 0,868 & 3,713 & 0,000 & 0,000 & 0 & 1,000 \\
\hline & Total within & & & & & 269,019 & 14 & 0,000 \\
\hline & Total between & & & & & 19,099 & 4 & 0,001 \\
\hline \multirow{4}{*}{ Jenjang Pendidikan } & SMA/MA/SMK & 5 & 0,788 & 6,814 & 0,000 & 69,667 & 4 & 0,000 \\
\hline & SMP/MTs & 14 & 0,999 & 13,602 & 0,000 & 216,077 & 13 & 0,000 \\
\hline & Total within & & & & & 285,744 & 17 & 0,000 \\
\hline & Total between & & & & & 2,374 & 1 & 0,123 \\
\hline \multirow{4}{*}{ Ukuran Sampel } & 30 atau kurang & 5 & 0,967 & 7,655 & 0,000 & 5,020 & 4 & 0,285 \\
\hline & 31 atau lebih & 14 & 0,930 & 13,060 & 0,000 & 283,033 & 13 & 0,000 \\
\hline & Total within & & & & & 288,053 & 17 & 0,000 \\
\hline & Total between & & & & & 0,065 & 1 & 0,798 \\
\hline
\end{tabular}

Berdasarkan Tabel 7, untuk karakteristik studi tahun penelitian, diperoleh informasi bahwa ukuran efek studi terendah adalah ukuran efek studi pada tahun penelitian 2012-2013, yang tergolong ukuran efek sedang, sedangkan ukuran efek studi tertinggi adalah ukuran efek studi pada tahun penelitian 2014-2015, yang tergolong ukuran efek kuat. Dalam sebuah penelitian lain, dikatakan bahwa pada tahun ajaran 2013-2014 mulai dilaksanakan kurikulum 2013, di mana salah satu model pembelajaran yang cocok dengan kurikulum 2013 tersebut adalah Model Pembelajaran Kooperatif (Yazidi, 2014). Dengan demikian, salah satu hal yang menyebabkan penelitian di tahun 2014-2015 memiliki ukuran efek yang kuat adalah karena baru dijalankannya kurikulum 2013 pada kisaran tahun tersebut dan Model Pembelajaran Kooperatif merupakan salah satu model pembelajaran yang ditekankan dalam kurikulum 2013 karena telah disesuaikan dengan permasalahan dan kondisi dalam dunia pendidikan saat itu. Dari ukuran efek yang diperoleh, dapat pula disimpulkan bahwa pada dasarnya penerapan Model Pembelajaran Kooperatif Tipe Think-Talk-Write memberikan pengaruh yang sedang atau kuat terhadap kemampuan komunikasi matematis siswa di seluruh kategori tahun penelitian. Dari kelima kategori tahun studi tersebut, terlihat pula bahwa ukuran efek studi mengalami naik turun setiap 2 tahun. Selain itu, diperoleh informasi bahwa p-value total between pada bagian 
heterogenitas adalah sebesar 0,001. Karena p-value $<0,05$ maka distribusi ukuran efek untuk kelima kategori pada karakteristik studi tersebut bersifat heterogen. Dengan demikian, terdapat perbedaan yang signifikan pada pengaruh penerapan Model Pembelajaran Kooperatif Tipe Think-Talk-Write terhadap kemampuan komunikasi matematis siswa berdasarkan tahun penelitian sehingga dapat disimpulkan bahwa penerapan Model Pembelajaran Kooperatif Tipe Think-Talk-Write untuk meningkatkan kemampuan komunikasi matematis siswa dipengaruhi oleh tahun penelitian.

Untuk karakteristik studi jenjang pendidikan, diperoleh informasi bahwa ukuran efek studi terendah adalah ukuran efek studi pada jenjang pendidikan SMA/MA/SMK, yang tergolong ukuran efek sedang sedangkan ukuran efek studi tertinggi adalah ukuran efek studi pada jenjang pendidikan SMP/MTs, yang juga tergolong ukuran efek sedang. Hal ini sejalan dengan penelitian lainnya yang menganalisis pengaruh penerapan Model Pembelajaran Kooperatif secara umum terhadap prestasi belajar matematika siswa, di mana ukuran efeknya juga tergolong sedang (Amin dkk., 2020). Selain itu, diperoleh informasi bahwa p-value total between pada bagian heterogenitas adalah sebesar 0,123. Karena p-value > 0,05 maka distribusi ukuran efek untuk kedua kategori pada karakteristik studi tersebut bersifat homogen. Dengan demikian, tidak terdapat perbedaan yang signifikan pada pengaruh penerapan Model Pembelajaran Kooperatif Tipe Think-Talk-Write terhadap kemampuan komunikasi matematis siswa berdasarkan jenjang pendidikan. Hal ini sejalan dengan penelitian lainnya yang menganalisis pengaruh penerapan Model Pembelajaran Kooperatif secara umum terhadap prestasi matematika siswa, di mana tidak terdapat perbedaan yang signifikan pada pengaruh penerapan Model Pembelajaran Kooperatif secara umum di negara Turki terhadap prestasi matematika siswa berdasarkan jenjang pendidikan (Turgut \& Turgut, 2018). Dengan demikian, dapat disimpulkan bahwa kemampuan komunikasi matematis siswa melalui penerapan Model Pembelajaran Kooperatif Tipe Think-Talk-Write tidak dipengaruhi oleh jenjang pendidikan dan model pembelajaran tersebut sama-sama cocok untuk diterapkan di jenjang pendidikan SMP/MTs maupun SMA/MA/SMK dengan besar pengaruh yang tergolong sedang.

Untuk karakteristik studi ukuran sampel, diperoleh informasi bahwa ukuran efek studi terendah adalah ukuran efek studi pada ukuran sampel 31 atau lebih, yang tergolong ukuran efek sedang sedangkan ukuran efek studi tertinggi adalah ukuran efek studi pada ukuran sampel 30 atau kurang yang juga tergolong ukuran efek sedang. Selain itu, diperoleh informasi bahwa p-value total between pada bagian heterogenitas adalah sebesar 0,798. Karena p-value > 0,05, maka distribusi ukuran efek untuk kedua kategori pada karakteristik studi tersebut bersifat homogen. Dengan demikian, tidak terdapat perbedaan yang signifikan pada pengaruh penerapan Model Pembelajaran Kooperatif Tipe Think-Talk-Write terhadap kemampuan komunikasi matematis siswa berdasarkan ukuran sampel. Oleh karena itu, dapat disimpulkan bahwa pada dasarnya kemampuan komunikasi matematis siswa melalui penerapan Model Pembelajaran Kooperatif Tipe Think-Talk-Write tidak dipengaruhi oleh ukuran sampel dan model pembelajaran tersebut sama-sama cocok untuk diterapkan di ukuran sampel 30 atau kurang, maupun 31 atau lebih. Dalam penelitian lainnya, disebutkan bahwa kelompok yang 
dibentuk dalam penerapan Model Pembelajaran Kooperatif Tipe Think-Talk-Write akan lebih efektif jika terdiri dari 5-6 siswa dengan jumlah kelompok sebanyak 6 kelompok, di mana hal ini membuat guru menjadi lebih mudah dalam melakukan pengawasan dan bimbingan untuk setiap kelompok (Laamena dkk., 2020). Hal tersebut sejalan dengan hasil yang diperoleh pada penelitian ini, di mana jumlah sampel untuk kelas eksperimen dan kelas kontrol pada studi primer berkisar antara 23-40 siswa, sehingga akan terbentuk sekitar 4-8 kelompok jika satu kelompoknya terdiri dari 5-6 siswa. Dengan demikian, jumlah kelompok yang berkisar 4-8 kelompok pun dapat dikatakan membuat penerapan Model Pembelajaran Kooperatif Tipe Think-Talk-Write berlangsung efektif.

Melalui berbagai temuan ini, dapat disimpulkan bahwa Model Pembelajaran Kooperatif Tipe Think-Talk-Write dapat dijadikan alternatif pembelajaran yang dapat membantu meningkatkan kemampuan komunikasi matematis siswa baik untuk diterapkan di jenjang pendidikan SMP/MTs maupun SMA/MA/SMK dan dengan ukuran sampel 30 atau kurang, maupun 31 atau lebih. Namun lebih disarankan apabila jumlah kelompok yang dibentuk dalam pembelajaran yang menerapkan Model Pembelajaran Kooperatif Tipe Think-Talk-Write adalah sebanyak 6 kelompok dengan masingmasing kelompok terdiri dari 5-6 siswa.

\section{KESIMPULAN}

Melalui hasil meta-analisis yang menggunakan 19 studi yang membahas tentang pengaruh penerapan Model Pembelajaran Kooperatif Tipe Think-Talk-Write terhadap kemampuan komunikasi matematis siswa, diperoleh informasi bahwa ukuran efek gabungan studi primer adalah 1,206, yang tergolong ke dalam ukuran efek yang kuat berdasarkan klasifikasi Cohen. Dengan demikian, dapat disimpulkan bahwa secara keseluruhan penerapan Model Pembelajaran Kooperatif Tipe Think-TalkWrite memberikan pengaruh yang kuat dan lebih signifikan terhadap kemampuan komunikasi matematis siswa dibandingkan dengan penerapan Model Pembelajaran Konvensional. Selain itu, ditinjau dari beberapa karakteristik studi, penerapan Model Pembelajaran Kooperatif Tipe ThinkTalk-Write untuk meningkatkan kemampuan komunikasi matematis siswa dipengaruhi oleh tahun penelitian, di mana ukuran efek tertinggi diperoleh pada tahun 2014-2015. Namun, penerapan Model Pembelajaran Kooperatif Tipe Think-Talk-Write untuk meningkatkan kemampuan komunikasi matematis siswa tidak dipengaruhi oleh jenjang pendidikan dan ukuran sampel. Berbagai temuan ini memberikan kontribusi bagi guru dan penentu kebijakan sehingga Model Pembelajaran Kooperatif Tipe Think-Talk-Write dapat dijadikan alternatif pembelajaran yang dapat membantu meningkatkan kemampuan komunikasi matematis siswa. Namun, penulis menyarankan agar studi ini dapat dikaji lebih lanjut lagi dengan menggunakan karakteristik studi yang lebih beragam lagi.

\section{REFERENSI}

Amin, M. K., Isnani, \& Paridjo. (2020). Meta Analisis Pengaruh Cooperative Learning terhadap Prestasi Belajar Matematika. Jurnal Prisma, 9(2), 221-233. DOI: 
https://doi.org/10.35194/jp.v9i2.1072

Astuti, A., \& Leonard. (2015). Peran Kemampuan Komunikasi Matematika Terhadap Prestasi Belajar Matematika Siswa. Jurnal Formatif, 2(2), 102-110.

Borenstein, M., Hedges, L. V., Higgins, J. P. T., \& Rothstein, H. R. (2009). Introduction to MetaAnalysis. Chicester: John Wiley \& Sons, Ltd.

Borenstein, M., Hedges, L. V., Higgins, J. P. T., \& Rothstein, H. R. (2010). A Basic Introduction to Fixed-Effect and Random-Effects Models for Meta-Analysis. Research Synthesis Methods, 1(2), 97-111. DOI: https://doi.org/10.1002/jrsm.12

Capar, G., \& Tarim, K. (2015). Efficacy of the Cooperative Learning Method on Mathematics Achievement and Attitude: A Meta-Analysis Research. Educational Sciences: Theory \& Practice, 15(2), 553-559. DOI: https://doi.org/10.12738/estp.2015.2.2098

Coe, R. (2002). It 's the Effect Size, Stupid. What Effect Size Is and Why It Is Important. Paper presented at the British Educational Research Association annual conference, Exeter.

Cohen, L., Manion, L., \& Morrison, K. (2007). Research Methods in Education 6th Edition. New York: Taylor \& Francis e-Library.

Fritz, C. O., Morris, P. E., \& Richler, J. J. (2012). Effect Size Estimates: Current Use, Calculations, and Interpretation. Journal of Experimental Psychology: General, 141(1), 2-18. DOI: https://doi.org/10.1037/a0024338

Greenhouse, J. B., \& Iyengar, S. (2009). Sensitivity Analysis and Diagnostics. In H. Cooper, V. L. Hedges, \& J. C. Valentine (Ed.), The Handbook of Research Synthesis and Meta-Analysis 2nd Edition, 417-433. New York: Russell Sage Foundation.

Hedges, L. V. (2009). Statistical Considerations. In H. Cooper, L. V. Hedges, \& J. C. Valentine (Ed.), The Handbook of Research Synthesis and Meta-Analysis 2nd Edition, 37-47. New York: Russell Sage Foundation.

Johnson, D. W., \& Johnson, R. T. (2014). Cooperative Learning in 21st Century. Anales de Psicología, 30(3), 841-851. DOI: https://doi.org/10.6018/analesps.30.3.201241

Juandi, D., \& Tamur, M. (2021). The Impact of Problem-Based Learning Toward Enhancing Mathematical Thinking: A Meta-Analysis Study. Journal of Engineering Science and Technology, 16(4), 3548-3561.

Jusniani, N., Setiawan, E., \& Inayah, S. (2020). Secondary School Students Mathematical Communication Through Think-Talk-Write (Ttw) Learning Model and Interactive Media. Journal of Physics: Conference Series, 1477(4). DOI: https://doi.org/10.1088/17426596/1477/4/042039

Laamena, C. M., Ngilawajan, D. A., \& Layn, I. S. (2020). Perbedaan Hasil Belajar Siswa Yang Diajarkan dengan Dua Model Pembelajaran Kooperatif (Studi Komparasi Model Pembelajaran Kooperatif Tipe Think Talk Write dan Think Pair Share Pada Siswa Kelas VII MTs Al-Irsyad Hutawa dalam Mempelajari Materi Operasi Hitung Bentuk Aljabar. Jar-Juir Jargaria (3J) 
Pengaruh Model Pembelajaran Kooperatif Tipe Think-Talk-Write terhadap Kemampuan Komunikasi Matematis Siswa: Studi Meta-Analisis, Nurmala Setianing Putri, Dadang Juandi, Al Jupri

Jurnal Sosial, Sains \& Humaniora, 1(1), 45-49.

Lomibao, L. S., Luna, C. A., \& Namoco, R. A. (2016). The Influence of Mathematical Communication on Students' Mathematics Performance and Anxiety. American Journal of Educational Research, 4(5), 378-382. DOI: https://doi.org/10.12691/education-4-5-3

Muhali. (2019). Pembelajaran Inovatif Abad Ke-21. Jurnal Penelitian dan Pengkajian Ilmu Pendidikan: e-Saintika, 3(2), 25-50. DOI: https://doi.org/10.36312/e-saintika.v3i2.126

Nelson, J. P. (2015). Meta-analysis: Statistical Methods. In R. J. Johnston, J. Rolfe, R. S. Rosenberger, \& R. Brouwer (Ed.), Benefit Transfer of Environmental and Resource Values, 329-356. Berlin: Springer. DOI: https://doi.org/10.1007/978-94-017-9930-0

Retnawati, H., Apino, E., Kartianom, Djidu, H., \& Anazifa, R. D. (2018). Pengantar Analisis Meta. Yogyakarta: Parama Publishing.

Sa'diyah, K. U., Ridlo, S., \& Wardono. (2019). Think Talk Write ( TTW ) Learning Model by Using Realia Towards Mathematical Communication Ability of Elementary School Students. Journal of Primary Education, 8(3), 254-261. DOI: https://doi.org/10.15294/jpe.v8i3.26613

Shah, A., Jones, M. P., \& Holtmann, G. J. (2020). Basics of Meta-Analysis. Indian Journal of Gastroenterology, 39(5), 503-513. DOI: https://doi.org/10.1007/s12664-020-01107-x

Shelby, L. B., \& Vaske, J. J. (2008). Understanding Meta-Analysis : A Review of the Methodological Literature. Leisure Sciences: An Interdisciplinary Journal, 30(2), 96-110. DOI: http://dx.doi.org/10.1080/01490400701881366

Tamur, M., Juandi, D., \& Kusumah, Y. S. (2020). The Effectiveness of the Application of Mathematical Software in Indonesia: A Meta-Analysis Study. International Journal of Instruction, 13(4), 867-884. DOI: https://doi.org/10.29333/iji.2020.13453a

Turgut, S., \& Turgut, I. G. (2018). The Effects of Cooperative Learning on Mathematics Achievement in Turkey: A Meta-Analysis Study. International Journal of Instruction, 11(3), 663-680. DOI: https://doi.org/10.12973/iji.2018.11345a

Umar, W. (2012). Membangun Kemampuan Komunikasi Matematis dalam Pembelajaran Matematika. Infinity Jurnal Ilmiah Program Studi Matematika STKIP Siliwangi Bandung, 1(1).

Wilson, D. B. (2009). Systematic Coding. In Harris Cooper, L. V. Hedges, \& J. C. Valentine (Ed.), The Handbook of Research Synthesis and Meta-Analysis 2nd Edition, 159-176. New York: Russell Sage Foundation.

Yazidi, A. (2014). Memahami Model-Model Pembelajaran dalam Kurikulum 2013 (The Understanding of Model of Teaching in Curriculum 2013). Jurnal Bahasa Sastra dan Pembelajarannya, 4(1), 89-95. 